\title{
CONTEXTUAL TEACHING AND LEARNING (CTL) SEBAGAI MODEL PEMBELAJ ARAN EKONOMI DALAM KBK
}

\author{
Oleh: Teguh Sihono \\ (Staf Pengajar di Fakultas I/mu Sosial Universitas Negeri Yogyakarta)
}

\begin{abstract}
Curriculum based on competency is a curriculum design developed based on a set of certain competencies. In Indonesia, -so far- education is dominated by idea saying that knowledge is a set of facts that have to be memorized. Classes focus on teacher as a main source of knowledge. It is need to find a new teaching and learning method so that it can develop student involvement. Contextual Teaching and Learning is a new strategy promoted, since this strategy is claimed can encourage students to construct knowledge into their own mind.
\end{abstract}

Key words: Inquiry, Competency, Contextual, Constructivism

\section{A. Pendahuluan}

Banyak model yang dapat digunakan untuk melaksanakan proses belajar mengajar (pembelajaran). Secara diametral model-model tersebut dapat dibedakan ke dalam dua model yang sangat berbeda, yaitu model ekspositori (expository) dan model inkuiri (inquiry teaching method). Sementara model-model lainnya terletak di antara dua model tersebut. Model pembelajaran (learning model) termasuk model pengajaran yang terpusat pada siswa (student centered instruction) atau model pengajaran inkuiri. Yaitu suatu model pengajaran yang menempatkan siswa dalam situasi di mana mereka harus berpartisipasi aktif untuk menemukan sesuatu untuk mereka sendiri. Belajar dengan inkuiri pada hakikatnya adalah suatu cara di mana murid menemukan sesuatu untuk dirinya sendiri. Model ekspositori lebih dikenal dengan model pengajaran di mana aktivitas dalam proses belajar mengajar didominasi oleh guru (pengajar).

Pengajaran (instruction/teaching), sudah tidak dipergunakan lagi dan dianggap usang, yang dikembangkan sekarang oleh para pakar di bidang pendidikan dan para guru adalah pembelajaran (/earning). Oleh karenanya yang akan dipaparkan dalam tulisan ini adalah tentang model-model pembelajaran (/earning models) ekonomi. Dalam mencapai penguasaan kompetensi 
dasar/tujuan pembelajaran dapat memilih berbagai macam model pembelajaran, dengan kelebihan dan kekurangannya masing-masing. Memang satu dengan yang lain mempunyai efektivitas yang berbeda untuk mencapai tujuan yang berbeda pula. Maka dari itu seorang pengajar (guru) dituntut untuk menguasai berbagai model pembelajaran, agar untuk kondisi, situasi, dan objek tertentu dapat dipilih atau pergunakan model pembelajaran yang sesuai/efektif.

Tahun ajaran baru 2004 nanti akan dilaksanakan/dipergunakan Kurikulum Berbasis Kompetensi (Competency Based Curriculum) untuk Sekolah Dasar (SD, MI), Sekolah Menengah Pertama (SMP, MTs), dan Sekolah Menengah Atas (SMA, Madrasah Aliyah). Kurikulum Berbasis Kompetensi (KBK) merupakan pengejawantahan dari strategi pendidikan kualitas hasilnya, dengan jalan merencanakan kompetensi tertentu yang harus dikuasai peserta didik setelah mengalami proses belajar. Kompetensi adalah kemampuan otentik (nyata/dapat ditampilkan) yang dimiliki seseorang sebagai hasil belajar. Kompetensi sebagai hasil belajar, dikuasai oleh siswa secara hirarkhis, artinya bahwa kompetensi kognitif mendasari kompetensi afektif, dan keduanya mendasari munculnya kompetensi psikomotorik. Paradigma pendidikan yang mengacu pada hasil belajar tertentu disebut Outcome Base Education (OBE). Paradigma pendidikan yang sampai saat ini masih dilaksanakan adalah Input Oriented Education yang salah satu cirinya yaitu adanya seleksi atau pemilihan calon peserta didik dengan berbagai cara. Kompetensi adalah outcome pendidikan yang harus dikuasai oleh peserta didik yang dapat ditampilkan baik secara sengaja maupun tidak sengaja. Oleh karena kompetensi hasil belajar tersebut bersifat otentik, maka penilaiannya atau pengujiannya juga bersifat otentik (Authentic Assessment), untuk menjamin bahwa seluruh kompetensi telah terbentuk secara komprehensif dan menjadi milik peserta didik secara permanen.

Kompetensi setiap mata pelajaran dan setiap jenjang pendidikan berbeda-beda. Kompetensi apa yang harus dikuasai peserta didik untuk mata pelajaran ekonomi, tentunya segala sesuatu yang berkenaan dengan ekonomi (usaha manusia di dalam mencapai kemakmuran). Misalnya, standar kompetensi pelajaran ekonomi yang harus dikuasai siswa sebagai hasil dari mempelajari ekonomi adalah : (1) mampu menganalisis perilaku pelaku ekonomi dalam kaitannya dengan kelangkaan, pengalokasian sumber daya dan barang, melalui mekanisme pasar, (2) mampu mendiskripsikan konsep ekonomi kemasyarakatan dan kebijakan pemerintah dalam bidang ekonomi, dan sebagainya. 


\section{B. Hakikat Belajar dan Mengajar 1. Hakikat Belajar}

Hakikat belajar adalah suatu aktivitas yang mengharapkan perubahan tingkah laku (behavioral change) pada diri individu yang belajar. Perubahan tingkah laku terjadi karena usaha individu yang bersangkutan. Belajar dipengaruhi oleh berbagai faktor : bahan yang dipelajari, faktor instrumental, faktor lingkungan, dan kondisi individual si pelajar. Faktorfaktor tersebut diatur sedemikian rupa, agar mempunyai pengaruh yang membantu tercapainya kompetensi secara optimal.

Proses belajar yang dimaksudkan untuk mencapai tujuan pendidikan dan pembelajaran merupakan proses yang kompleks dan senantiasa berlangsung dalam berbagai situasi dan kondisi. Masukan sistem pendidikan/sistem belajar adalah orang, informasi, dan sumber lain. Sedangkan keluaran terdiri dari orang/siswa dengan penampilan yang lebih maju dalam berbagai aspek.

Pada prinsipnya belajar adalah proses perubahan tingkah laku sebagai akibat dari interaksi antara siswa dengan sumber-sumber belajar, baik sumber yang didesain maupun yang dimanfaatkan. Proses belajar tidak hanya terjadi karena adanya interaksi antara siswa dengan guru, bahkan hasil belajar yang maksimal dapat pula diperoleh lewat interaksi antara siswa dengan sumber-sumber belajar lainnya.
Untuk memberikan landasan filosofis terhadap pelaksanaan pembelajaran khususnya jenjang SMP dan SMA, maka perlu dikemukakan sejumlah pandangan dari para ahli pendidikan dan pembelajaran. Ada tiga pakar pendidikan yang teorinya dapat dipergunakan sebagai acuan dalam mengembangkan dan mengimplementasikan Kurikulum Berbasis Kompetensi (KBK), yaitu John Dewey, Vygotsky, dan David Ausubel.

Menurut Dewey (1974), tugas sekolah adalah memberi pengalaman belajar yang tepat bagi siswa. Tugas guru adalah membantu siswa menjalin pengalaman belajar yang satu dengan yang lain, termasuk yang baru dengan yang lama. Pengalaman baru dengan pengalaman belajar yang lama akan melekat pada struktur kognitif siswa dan menjadi pengetahuan baru bagi siswa.

Menurut Vygotsky (2001) terdapat hubungan yang erat antara pengalaman sehari-hari dengan konsep keilmuan (Scientific), tetapi ada perbedaan secara kualitatif antara berpikir kompleks dan berpikir konseptual. Berpikir kompleks berdasarkan pada pengkategorisasian objek berdasarkan suatu situasi, dan berpikir konseptual berbasis pada pengertian yang lebih abstrak. Pengembangan kemampuan menganalisis, membuat hipotesis, dan menguji pengalaman sehari-hari. Kemampuan ini tidak saja ditentukan pengalaman, tetapi tergantung pada tipe spesifik interaksi sosial. 
Menurut Ausubel (1979), pengalaman belajar baru akan masuk ke dalam memori jangka panjang dan akan menjadi pengetahuan baru apabila memiliki makna. Pengalaman belajar adalah interaksi antara subjek belajar dengan bahan ajar, misalnya siswa mengerjakan tugas membaca, melakukan pemecahan masalah, mengamati suatu gejala, peristiwa, percobaan, dan sejenisnya. Agar supaya pengalaman yang baru menjadi pengetahuan baru, semua konsep dalam mata pelajaran diusahakan memiliki nilai terapan di lapangan.

\section{Hakikat Mengajar}

Seperti pendapatnya Bruce Jouce dan Marsha Weil (1992), bahwa hakikat mengajar (teaching) adalah membantu siswa memperoleh informasi, ide, ketrampilan, nilai, cara berpikir, sarana untuk mengekspresikan dirinya, dan cara-cara bagaimana belajar. Hasil akhir atau hasil jangka panjang dari proses mengajar adalah kemampuan siswa yang tinggi untuk dapat belajar dengan mudah dan efektif di masa mendatang. Dengan demikian hakikat mengajar adalah memfasilitasi siswa dalam belajar agar mereka mendapatkan kemudahan dalam belajar.

\section{Pembelajaran dalam Kurikulum Berbasis Kompetensi (KBK)}

1. Konsep Dasar

Pembelajaran dapat diartikan sebagai proses membuat orang belajar.
Tujuannya adalah membantu belajar, atau memanipulasi lingkungan sehingga memberi kemudahan bagi orang yang belajar. Gagne R.M. dan Briggs (1979) mendefinisikan pembelajaran sebagai suatu rangkaian events (kejadian, peristiwa, kondisi, dsb.) yang secara sengaja dirancang untuk mempengaruhi pembelajar, sehingga proses belajarnya dapat berlangsung dengan mudah. Pembelajaran bukan hanya terbatas pada kejadian yang dilakukan guru saja, melainkan mencakup semua kejadian kegiatan yang mungkin mempunyai pengaruh langsung pada proses belajar manusia.

Pembelajaran mencakup pula kejadian-kejadian yang diturunkan oleh bahan-bahan cetak, gambar, program radio, televisi, film, slide, maupun kombinasi dari bahan-bahan tersebut. Bahkan saat ini pemanfaatan berbagai program komputer untuk pembelajaran, atau dikenal dengan nama E-Learning (Electronic-Learning) berupa CAl (Computer Assisted Instruction) atau CAL (Computer Assisted Learning), belajar lewat internet, SIG (Sistem Information Geography) pendidikan, web-side sekolah, dan lain sebagainya, yang sudah secara luas digunakan dalam pembelajaran.

\section{Pendidikan dan Pembelajaran Berbasis Kompetensi}

Kurikulum Berbasis Kompetensi adalah suatu desain kurikulum yang dikembangkan berdasarkan seperangkat 
kompetensi tertentu. Kompetensi adalah suatu kemampuan melakukan sesuatu (the ability to do something) yang berbeda dengan kemampuan mengetahui sesuatu. Pendapat lain "Competence as the knowledge, skills, and abilities or capabilities that a person achieves, which become of his or her being to the exent he or she can satisfactoriry perform particular cognitive, affective, and psychomotor behaviors" (Mc Ashan. 1979 :45)

Ciri-ciri Kurikulum

Berbasis

Kompetensi :

a. menekankan pada ketercapaian kompetensi secara individual maupun klasikal.

b. berorientasi pada hasil dan keberagaman.

c. penyampaian pembelajaran menggunakan pendekatan dan metode yang variatif.

d. sumber belajar bukan hanya guru tetapi juga sumber belajar lain yang memenuhi unsur edukatif.

e. penilaian menekankan pada proses dan hasil belajar (penguasaan kompetensi).

Pendekatan dalam pengembangan Kurikulum Berbasis Kompetensi (KBK) harus dicirikan oleh hal-hal sebagai berikut :

a. orientasi pencapaian hasil dan dampaknya (outcome oriented)

b. berbasis pada standar kompetensi dan kompetensi dasar c. bertolak dari kompetensi tamatan/lulusan

d. pengembangan kurikulum berdiferensiasi

e. utuh dan menyeluruh (holistik)

f. menerapkan prinsip ketuntasan belajar (mastery learning)

Pendidikan Berbasis Kompetensi adalah bentuk pendidikan yang diselenggarakan untuk menyiapkan lulusannya menguasai seperangkat kompetensi yang dapat bermanfaat bagi kehidupannya kelak. Secara lebih singkat dapat dikatakan bahwa pendidikan berbasis kompetensi adalah pendidikan yang mengacu pada kompetensi yang akan dicapai dan diperlukan oleh siswa. Sehingga (KBK) merupakan bagian dari Pendidikan Berbasis Kompetensi. Pendidikan Berbasis Kompetensi sebagai suatu sistem tersusun dari rangkaian unsur-unsur yang saling terkait, yaitu ; standar kompetensi, kurikulum yang dikembangkan berdasarkan kompetensi, penyelenggaraan proses belajar mengajar, evaluasi berdasarkan kompetensi, sertifikasi

Standar Kompetensi adalah kebulatan pengetahuan, ketrampilan, sikap, dan tingkat penguasaan yang diharapkan dicapai dalam mempelajari suatu mata pelajaran.

Pendidikan Berbasis Kompetensi memiliki beberapa karakteristik .

a. Kompetensi yang akan dicapai siswa diidentifikasi berdasarkan apa yang 
siswa harus memahami dan mampu melakukan

b. Kriteria digunakan untuk menilai setiap kompetensi yang telah dikemukakan

c. Bahan ajar dikembangkan berdasarkan standar kompetensi yang ditetapkan

d. Penilaian berdasarkan standar kompetensi

e. Kemajuan pembelajaran didasarkan atas pencapaian kompetensi.

Pembelajaran Berbasis Kompetensi adalah program pembelajaran di mana hasil belajar atau kompetensi yang diharapkan dicapai oleh siswa, sistem pencapaian, dan indikator pencapaian hasil belajar dirumuskan secara tertulis sejak perencanaan dimulai. Manfaat yang diperoleh jika melaksanakan pembelajaran berbasis kompetensi.

a. Menghindari duplikasi dalam pemberian materi pembelajaran.

b. Mengupayakan konsistensi kompetensi yang ingin dicapai dalam mengajarkan suatu mata pelajaran.

c. Meningkatkan pembelajaran sesuai dengan kebutuhan, kecepatan, dan kesempatan siswa.

d. Membantu mempermudah pelaksanaan akreditasi.

e. Memperbaharui sistem evaluasi dan pelaporan hasil belajar siswa.

f. Memperjelas komunikasi dengan siswa tentang tugas, kegiatan, atau pengalaman belajar yang harus dilakukan dan cara yang digunakan untuk menentukan keberhasilan belajarnya.

g. Meningkatkan akuntabilitas publik

h. Memperbaiki sistem sertifikasi

D. Contextual Teaching and Learning (CTL) Sebagai Model Pembelajaran Ekonomi dalam Kurikulum Berbasis Kompetensi (KBK)

\section{Pendekatan Kontekstual}

Agar supaya pembelajaran yang diselenggarakan dapat memaksimisasikan manfaat, maka perlu dipilih suatu pendekatan atau model pembelajaran yang sesuai dan efektif untuk suatu mata pelajaran tertentu. Dalam pembelajaran mata pelajaran ekonomi saat ini baru dikembangkan beberapa pendekatan/model pembelajaran, yang diyakini memiliki efektivitas, produktivitas, dan kemanfaatan besar, serta bermakna. Salah satu model pembelajaran tersebut yakni pendekatan/model Contextual Teaching and Learning (CTL).

\section{a. Latar Belakang}

Pengetahuan dibangun oleh manusia sedikit demi sedikit, yang hasilnya diperluas melalui konteks yang terbatas (sempit), dan tidak sekonyong-konyong. Pengetahuan bukanlah seperangkat fakta-fakta, konsep, atau kaidah yang siap untuk diambil dan diingat. Manusia harus mengkonstruksi pengetahuan itu dan memberi makna melalui pengalaman nyata. Filosofi inilah yang mendasari 
pengembangan pendekatan kontekstual (Contextual Teaching and Learning, CTL).

Pendekatan kontekstual merupakan konsep belajar yang membantu guru mengaitkan antara materi yang diajarkan dengan situasi dunia nyata siswa dan mendorong siswa membuat hubungan antara pengetahuan yang dimilikinya dengan penerapannya dalam kehidupan mereka sebagai anggota keluarga dan masyarakat. Dengan konsep ini, hasil pembelajaran diharapkan lebih bermakna bagi siswa. Proses pembelajaran berlangsung alamiah dalam bentuk kegiatan siswa bekerja dan mengalami, bukan transfer pengetahuan dari guru ke siswa. Strategi pembelajaran lebih dipentingkan daripada hasil.

Dalam konteks ini, siswa perlu mengerti apa makna belajar, apa manfaatnya, dalam status apa mereka, dan bagaimana mencapainya. Mereka sadar bahwa yang mereka pelajari berguna bagi hidupnya kelak. Dengan demikian mereka memposisikan sebagai diri sendiri yang memerlukan suatu bekal untuk hidupnya kelak. Mereka mempelajari apa yang bermanfaat bagi dirinya dan berupaya menggapainya. Dalam upayanya itu, mereka memerlukan guru sebagai pengarah dan pembimbing.

Dalam kelas kontekstual, tugas guru adalah membantu siswa mencapai tujuannya. Maksudnya, guru lebih banyak berurusan dengan strategi daripada memberi informasi. Tugas guru mengelola kelas sebagai sebuah tim yang bekerja bersama untuk menemukan sesuatu yang baru bagi anggota kelas (siswa). Sesuatu yang baru (pengetahuan dan ketrampilan) datang dari "menemukan sendiri", bukan dari "apa kata guru". Begitulah peran guru di kelas yang dikelola dengan pendekatan kontekstual.

Kontekstual hanyalah sebuah strategi pembelajaran, seperti halnya strategi pembelajaran yang lain, kontekstual dikembangkan dengan tujuan agar pembelajaran berjalan lebih produktif dan bermakna. Pendekatan kontekstual dapat dijalankan tanpa harus mengubah kurikulum dan tatanan yang ada. Dalam tulisan ini akan dibahas persoalan yang berkenaan dengan pendekatan kontekstual dan implikasi penerapannya.

\section{b. Mengapa Pendekatan Kontekstual Menjadi Pilihan}

Ada beberapa alasan mengapa pendekatan kontekstual menjadi pilihan dalam pendekatan pembelajaran yaitu :

1) Sejauh ini pendidikan kita masih didominasi oleh pandangan bahwa pengetahuan sebagai perangkat fakta yang harus dihafal. Kelas masih berfokus pada guru sebagai sumber utama pengetahuan, ceramah menjadi pilihan utama strategi belajar. Untuk itu diperlukan "strategi belajar baru" yang lebih memberdayakan siswa. Strategi belajar yang tidak memaksakan 
siswa untuk menghafal fakta, tetapi yang mendorong siswa mengkonstruksikan pengetahuan di benak mereka sendiri.

2) Melalui landasan konstruktivisme, CTL "dipromosikan" menjadi alternatif strategi belajar yang baru. Melalui CTL ini, siswa diharapkan belajar melalui mengalami, bukan menghafal.

3) Knowledge is constructed by humans. Knowledge is not a set of facts, concepts, or low waiting to be discovered. Its is not something that exists independent of a known. Humans create or construct knowledge as they attempt to bring meaning to their experience. Everything that we know, we have made (Zahorik. 1995).

4) Knowledge is conjectural and fallible.

Since knowledge is construction of humans and humans constantly under going new experiences, knowledge can never by stable. The understandings that we invent are always tentative and incomplete. Knowledge grows through exposure. Understand becomes deeper and stronger if one test it against new encounters (Zahorik. 1995).

\section{c. Kecenderungan Pemikiran Tentang Belajar}

Pendekatan kontekstual mendasarkan diri pada kecenderungan pemikiran tentang belajar sebagai berikut:

\section{1) Proses Belajar}

a) Belajar tidak sekedar menghafal, tetapi siswa harus mengkonstruksikan pengetahuan di benak mereka sendiri

b) Anak belajar dari mengalami. Anak mencatat sendiri pola-pola bermakna dari pengetahuan baru, dan bukan diberi begitu saja oleh guru.

c) Para ahli berpendapat bahwa pengetahuan yang dimiliki seseorang itu terorganisasi dan mencerminkan pemahaman yang mendalam tentang sesuatu persoalan (subject matter)

d) Pengetahuan tidak dapat dipisahkan-pisahkan menjadi fakta-fakta, tetapi mencerminkan ketrampilan yang dapat diterapkan.

e) Manusia mempunyai tingkatan yang berbeda dalam menyikapi situasi baru

f) Siswa perlu dibiasakan memecahkan masalah, menemukan sesuatu yang berguna bagi dirinya, dan bergelut dengan ide-ide.

g) Proses belajar dapat mengubah struktur otak. Perubahan struktur otak berjalan seiring dengan perkembangan organisasi pengetahuan dan ketrampilan seseorang. Maka perlu dipahami strategi belajar yang salah dan yang terus-menerus dijalankan 
(dibiarkan terbuka) akan mempengaruhi struktur otak, yang pada akhirnya mempengaruhi cara seseorang berperilaku.

\section{2) Transfer Belajar}

a) Siswa belajar dari mengalami sendiri, bukan dari pemberian orang lain

b) Ketrampilan dan pengetahuan itu diperluas dari konteks yang terbatas (sempit), sedikit-demi sedikit.

c) Penting bagi siswa tahu untuk apa ia belajar, dan bagaimana ia menggunakan pengetahuan dan ketrampilan itu.

\section{3) Siswa Sebagai Pembelajar}

a) Manusia mempunyai kecenderungan untuk belajar dalam hal tertentu, dan seorang anak mempunyai kecenderungan untuk belajar dengan cepat tentang hal-hal baru.

b) Strategi belajar itu penting. Anak dengan mudah mempelajari sesuatu yang baru, akan tetapi untuk hal-hal yang sulit, strategi belajar sangatlah penting.

c) Peran orang dewasa (guru) membantu menghubungkan antara yang baru dan yang sudah diketahui.

d) Tugas guru memfasilitasi, agar informasi baru bermakna, memberi kesempatan kepada siswa untuk menemukan dan menerapkan ide mereka sendiri, dan menyadarkan siswa untuk menerapkan strategi mereka sendiri.

\section{4) Pentingnya Lingkungan Belajar}

a) Belajar efektif itu dimulai dari lingkungan belajar yang berpusat pada siswa. Dari guru akting di depan kelas, siswa menonton, ke siswa akting bekerja dan berkarya, guru mengarahkan.

b) Pengajaran harus berpusat pada bagaimana cara siswa menggunakan pengetahuan barunya. Strategi belajar lebih dipentingkan dibanding hasilnya

c) Umpan balik amat penting bagi siswa, yang berasal dari proses penilaian (assessment) yang benar.

d) Pentingnya menumbuhkan komunitas belajar dalam bentuk kerja kelompok.

\section{d. Hakikat Pembelajaran}

\section{Kontekstual}

Pembelajaran kontekstual (Contextual Teaching and Learning) adalah konsep belajar yang membantu guru mengaitkan antara materi yang diajarkannya dengan situasi dunia nyata siswa dan mendorong siswa membuat hubungan antara pengetahuan yang dimilikinya dengan penerapannya dalam kehidupan mereka sehari-hari, dengan melibatkan tujuh komponen utama pembelajaran efektif, yakni : konstruktivisme (Constructivism), bertanya (Questioning), menemukan 
(/nquiry), masyarakat belajar (Learning Community), permodelan (Modeling), refleksi (Reflection), dan penilaian sebenarnya (Authentic Assessment).

Ada suatu motto : "Students learn best by actively constructing their own understanding " (CTL Academy Fellow. 1999). Artinya Cara belajar terbaik adalah siswa mengkonstruksikan sendiri secara aktif pemahamannya.

e. Kata-Kata Kunci Pembelajaran

1) Real world learning

2) Mengutamakan pengalaman nyata

3) Berpikir tingkat tinggi

4) Berpusat pada siswa

5) Siswa aktif, kritis dan kreatif

6) Pengetahuan bermakna dalam kehidupan

7) Dekat dengan kehidupan nyata

8) Siswa proaktif, bukan menghafal

9) Learning bukan teaching

10) Education bukan instruction

11) Pembentukan manusia

12) Memecahkan masalah

13) Siswa akting, guru mengarahkan

14) Perubahan perilaku

15) Hasil belajar diukur dengan berbagai cara bukan hanya dengan tes f. Lima Elemen Belajar yang Konstruktivistik

1) Activating knowledge (pengaktifan pengetahuan yang sudah ada)

2) Acquiring knowledge (pemerolehan pengetahuan baru) dengan cara mempelajari secara keseluruhan dulu, kemudian memperhatikan detailnya.

3) Understanding knowledge (Pemahaman pengetahuan) : dengan cara menyusun konsep sementara/hipotesis, (2) melakukan sharing kepada orang lain agar mendapat tanggapan/validasi, (3) konsep tersebut direvisi dan dikembangkan.

4) Applying knowledge (mempraktikkan pengetahuan dan pengalaman tersebut)

5) Reflecting knowledge (melakukan refleksi terhadap strategi pengembangan pengetahuan tersebut (Zahorik. $1995: 14-22)$

\section{g. Perbedaan Pendekatan Kontekstual dengan Pendekatan Tradisional}

\begin{tabular}{|l|l|l|}
\hline No & \multicolumn{1}{|c|}{ PENDEKATAN CTL } & \multicolumn{1}{|c|}{ PENDEKATAN TRADI SI ONAL } \\
\hline 1 & $\begin{array}{l}\text { Siswa secara aktif terlibat dalam proses } \\
\text { pembelajaran }\end{array}$ & $\begin{array}{l}\text { Siswa adalah penerima informasi } \\
\text { secara pasif }\end{array}$ \\
\hline 2 & $\begin{array}{l}\text { Siswa belajar dari teman melalui kerja } \\
\text { kelompok, diskusi, saling mengoreksi }\end{array}$ & Siswa belajar secara individual \\
\hline
\end{tabular}




\begin{tabular}{|c|c|c|}
\hline No & PENDEKATAN CTL & PENDEKATAN TRADI SI ONAL \\
\hline 3 & $\begin{array}{l}\text { Pembelajaran dikaitkan dengan kehidupan } \\
\text { nyata dan atau masalah yang disimulasikan }\end{array}$ & $\begin{array}{l}\text { Pembelajaran sangat abstrak dan } \\
\text { teoretis }\end{array}$ \\
\hline 4 & Perilaku dibangun atas kesadaran diri & Perilaku dibangun atas kebiasaan \\
\hline 5 & $\begin{array}{l}\text { Ketrampilan dikembangkan atas dasar } \\
\text { pemahaman }\end{array}$ & $\begin{array}{lll}\text { Ketrampilan dikembangkan atas } \\
\text { dasar latihan }\end{array}$ \\
\hline 6 & $\begin{array}{l}\text { Hadiah untuk perilaku baik adalah kepuasan } \\
\text { diri }\end{array}$ & $\begin{array}{l}\text { Hadiah untuk perilaku baik adalah } \\
\text { pujian atau nilai (angka ) rapor }\end{array}$ \\
\hline 7 & $\begin{array}{l}\text { Seseorang tidak melakukan yang jelek karena } \\
\text { dia sadar hal itu keliru dan merugikan }\end{array}$ & $\begin{array}{l}\text { Seseorang tidak melakukan yang } \\
\text { jelek karena dia takut hukuman }\end{array}$ \\
\hline 8 & $\begin{array}{l}\text { Bahasa diajarkan dengan pendekatan } \\
\text { komunikatif, yakni siswa diajak menggunakan } \\
\text { bahasa dalam konteks nyata }\end{array}$ & $\begin{array}{lcr}\text { Bahasa } & \text { diajarkan } & \text { dengan } \\
\text { pendekatan } & \text { struktural, } & \text { rumus } \\
\text { diterangkan } & \text { sampai } & \text { paham, } \\
\text { kemudian dilatihkan (drill) } & \end{array}$ \\
\hline 9 & $\begin{array}{l}\text { Pemahaman rumus dikembangkan atas dasar } \\
\text { skemata yang sudah ada dalam diri siswa }\end{array}$ & $\begin{array}{l}\text { Rumus itu ada di luar diri siswa, } \\
\text { yang harus diterangkan, diterima, } \\
\text { dihafalkan, dan dilatihkan }\end{array}$ \\
\hline 10 & $\begin{array}{l}\text { Pemahaman rumus itu relatif berbeda antara } \\
\text { siswa yang satu dg yang lain, sesuai dengan } \\
\text { skema siswa (ongoing process of } \\
\text { development) }\end{array}$ & $\begin{array}{l}\text { Rumus adalah kebenaran absolut } \\
\text { (sama untuk semua orang). Hanya } \\
\text { ada dua kemungkinan, yaitu } \\
\text { pemahaman rumus yang salah atau } \\
\text { pemahaman rumus yang benar. }\end{array}$ \\
\hline 11 & $\begin{array}{l}\text { Siswa menggunakan kemampuan berpikir } \\
\text { kritis, terlibat penuh dalam mengupayakan } \\
\text { terjadinya proses pembelajaran yang efektif, } \\
\text { ikut bertanggung jawab atas terjadinya proses } \\
\text { pembelajaran efektif, dan membawa skemata } \\
\text { masing-masing ke dalam proses pembelajaran }\end{array}$ & $\begin{array}{l}\text { Siswa secara pasif menerima rumus } \\
\text { atau kaidah } \text { (membaca, } \\
\text { mendengarkan, } \\
\text { menghafal), tanpa memberikan } \\
\text { kontribusi ide dalam proses } \\
\text { pembelajaran. }\end{array}$ \\
\hline 12 & $\begin{array}{l}\text { Pengetahuan yang dimiliki manusia } \\
\text { dikembangkan oleh manusia itu sendiri. } \\
\text { Manusia menciptakan atau membangun } \\
\text { pengetahuan dg cara memberi arti dan } \\
\text { memahami pengalamannya. }\end{array}$ & $\begin{array}{l}\text { Pengetahuan adalah penangkapan } \\
\text { terhadap serangkaian fakta, konsep, } \\
\text { atau hukum yang berada di luar diri } \\
\text { manusia }\end{array}$ \\
\hline 13 & $\begin{array}{l}\text { Karena ilmu pengetahuan itu dikembangkan } \\
\text { (dikonstruksi) oleh manusia sendiri, } \\
\text { sementara manusia selalu mengalami } \\
\text { peristiwa baru, maka pengetahuan itu tidak } \\
\text { pernah stabil, selalu berkembang (tentative \& } \\
\text { incomplete) }\end{array}$ & $\begin{array}{l}\text { Kebenaran bersifat absolut dan } \\
\text { pengetahuan bersifat final }\end{array}$ \\
\hline 14 & Siswa diminta bertanggung jawab memonitor & Guru adalah penentu jalannya \\
\hline
\end{tabular}




\begin{tabular}{|c|c|c|}
\hline No & PENDEKATAN $C T L$ & PENDEKATAN TRADI SI ONAL \\
\hline & $\begin{array}{l}\text { dan mengembangkan pembelajaran mereka } \\
\text { masing-masing }\end{array}$ & proses pembelajaran \\
\hline 15 & $\begin{array}{l}\text { Penghargaan terhadap pengalaman siswa } \\
\text { sangat diutamakan }\end{array}$ & $\begin{array}{l}\text { Penghargaan tidak memperhatikan } \\
\text { pengalaman siswa }\end{array}$ \\
\hline 16 & $\begin{array}{l}\text { Hasil belajar diukur dengan berbagai cara: } \\
\text { proses bekerja, hasil karya, penampilan, } \\
\text { rekaman, tes, dam lain-lain. }\end{array}$ & $\begin{array}{l}\text { Hasil belajar hanya diukur dengan } \\
\text { hasil tes }\end{array}$ \\
\hline 17 & $\begin{array}{l}\text { Pembelajaran terjadi di berbagai tempat, } \\
\text { konteks, dan setting }\end{array}$ & $\begin{array}{l}\text { Pembelajaran hanya terjadi dalam } \\
\text { kelas }\end{array}$ \\
\hline 18 & $\begin{array}{l}\text { Penyesalan adalah hukuman dari perilaku } \\
\text { jelek }\end{array}$ & $\begin{array}{l}\text { Sanksi adalah hukuman dari perilaku } \\
\text { jelek }\end{array}$ \\
\hline 19 & Perilaku baik berdasarkan motivasi intrinsik & $\begin{array}{l}\text { Perilaku baik berdasarkan motivasi } \\
\text { ekstrinsik }\end{array}$ \\
\hline 20 & $\begin{array}{l}\text { Seseorang berperilaku baik karena dia yakin } \\
\text { itulah yang terbaik dan bermanfaat. }\end{array}$ & $\begin{array}{l}\text { Seseorang berperilaku baik karena } \\
\text { dia terbiasa melakukan begitu. } \\
\text { Kebiasaan ini dibangun dg hadiah } \\
\text { yang menyenangkan }\end{array}$ \\
\hline
\end{tabular}

h. Strategi Pengajaran yang Berasosiasi dengan CTL.

1) CBSA (cara Belajar Siswa Aktif)

2) Pendekatan proses

3) Life skills education

4) Authentic instruction

5) Project-Based Learning

6) Inquiry-Based Learning

7) Problem-Base Learning

8) Cooperative-Learning

9) Service Learning

10) Work-Based Learning

\section{E. Penerapan Pendekatan Kontekstual di Kelas}

Pendekatan kontekstual memiliki tujuh komponen utama, yaitu konstruktivisme (Constructivism), bertanya (Questioning), menemukan (/nquiry), masyarakat belajar (Learning Community), permodelan (Modeling), refleksi (Reflection), dan penilaian sebenarnya (Authentic Assessment). Suatu kelas dikatakan menggunakan pendekatan kontekstual (CTL), jika menerapkan ke tujuh komponen tersebut dalam pembelajarannya. Untuk melaksanakan hal itu tidaklah sulit, karena CTL dapat diterapkan dalam segala macam kurikulum, bidang studi apa saja, dan kelas yang bagaimanapun. Langkah-langkah penerapan CTL dalam kelas, adalah sebagai berikut.

1. Kembangkan pemikiran :anak akan belajar lebih bermakna dengan cara bekerja sendiri, menemukan sendiri, mengkonstruksi sendiri pengetahuan dan ketrampilan barunya 
2. Laksanakan sejauh mungkin kegiatan inkuiri untuk semua topik

3. Kembangkan sifat ingin tahu siswa dengan bertanya

4. Ciptakan masyarakat belajar atau belajar dalam kelompok-kelompok

5. Hadirkan model sebagai contoh pembelajaran

6. Lakukan refleksi di akhir pertemuan

7. Lakukan penilaian yang sebenarnya dengan berbagai cara.

1. Tujuh Komponen Contextual Teaching and Learning (CTL)

a. Konstruktivisme

\section{(Constructivism)}

Konstruktivisme merupakan landasan berpikir (filosofi) pendekatan CTL, yaitu bahwa pengetahuan dibangun oleh manusia sedikit demi sedikit, yang hasilnya diperluas melalui kontes yang terbatas (sempit) dan tidak sekonyongkonyong. Pengetahuan bukanlah seperangkat fakta, konsep, atau hukum/kaidah yang siap untuk diambil dan diingat. Manusia harus mengkonstruksi pengetahuan itu dan memberi makna melalui pengalaman nyata. Siswa dibiasakan memecahkan masalah, menemukan sesuatu yang berguna bagi dirinya, dan bergelut dengan ide-ide. Guru tidak mampu memberikan semua pengetahuan kepada siswa. Siswa harus mengkonstruksi pengetahuan di benak mereka sendiri. Esensi dari teori konstruktivistik adalah ide bahwa siswa harus menemukan dan mentransformasikan suatu informasi kompleks ke situasi lain, dan apabila dikehendaki, informasi itu menjadi milik mereka sendiri. Dengan demikian pembelajaran harus dikemas menjadi proses mengkonstruksi bukan menerima pengetahuan.

Landasan berpikir konstruktivisme agak berbeda dengan pandangan kaum objektivis, yang lebih menekankan pada hasil pembelajaran. Dalam pandangan konstruktivis, strategi memperoleh lebih diutamakan dibandingkan dengan seberapa banyak siswa memperoleh dan mengingat pengetahuan. Untuk itu tugas guru adalah memfasilitasi proses tersebut dengan:

1) menjadikan pengetahuan bermakna dan relevan bagi siswa

2) memberi kesempatan siswa menemukan dan menerapkan idenya sendiri

3) menyadarkan siswa agar menerapkan strategi mereka sendiri dalam belajar.

Pengetahuan tumbuh dan berkembang melalui pengalaman. Pemahaman berkembang semakin dalam dan semakin kuat apabila selalu diuji dengan pengalaman baru. Menurut Piget, manusia memiliki struktur pengetahuan dalam otaknya, seperti kotak-kotak yang masing-masing berisi informasi bermakna yang berbeda-beda. Pengalaman yang sama bagi beberapa orang akan dimaknai yang berbeda, dan disimpan dalam kotak yang berbeda. Pengalaman baru akan dihubungkan dengan kotak- 
kotak (struktur pengetahuan) dalam otak manusia. Struktur pengetahuan dikembangkan dalam otak manusia dengan dua cara, yaitu assimilasi atau akomodasi. assimilasi maksudnya struktur pengetahuan baru dibuat atau dibangun atas dasar struktur pengetahuan yang sudah ada. Akomodasi maksudnya struktur pengetahuan yang sudah ada dimodifikasi untuk menampung dan menyesuaikan dengan hadirnya pengalaman baru.

Penerapannya di kelas, pada umumnya kita sudah menerapkan filosofi ini dalam pembelajaran sehari-hari, yaitu ketika kita merancang pembelajaran dalam bentuk siswa bekerja, praktik mengerjakan sesuatu, berlatih secara fisik, menulis karangan, mendemonstrasikan, menciptakan ide, dan sebagainya. Kita tinggal mengembangkan cara-cara tersebut lebih banyak lagi.

\section{b. Menemukan (/nquiry)}

Menemukan merupakan kegiatan inti dari pembelajaran berbasis CTL. Pengetahuan dan ketrampilan yang diperoleh siswa diharapkan bukan hasil mengingat seperangkat fakta-fakta, tetapi hasil dari menemukan sendiri. Guru harus selalu merancang kegiatan yang merujuk pada kegiatan menemukan, apapun materi yang diajarkan. Topik kelangkaan barang dan faktor produksi, sudah seharusnya ditemukan sendiri oleh siswa, bukan menurut buku atau guru.

Siklus inkuiri : Observasi (observing), bertanya (questioning), mengajukan dugaan (hipotesis), pengumpulan data (data gathering), dan penyimpulan (conclusion).

Langkah-langkah kegiatan menemukan (inkuiri)

1) Merumuskan masalah, misalnya : bagaimana bisa menjelaskan kelangkaan, mengidentifikasi barang apa yang akan dibuat, bagaimana cara membuat barang tadi, dan untuk siapa barang tersebut dibuat?

2) Mengamati atau melakukan observasi, misalnya membaca buku, menanyakan kepada sumber lain (teman, kakak, orang tua, dsb). Mengamati dan mengumpulkan data tentang barang-barang yang dijual di pasar, kegiatan yang dilakukan oleh tetangga dalam mendapatkan penghasilan.

3) Menganalisis dan menyajikan hasil dalam tulisan, gambar, laporan, bagan, tabel, dan karya lainnya
a) siswa menuliskan laporan hasil pengamatan di pasar atau di lingkungan tempat tinggal siswa.
b) siswa membuat diagram interaksi pelaku ekonomi (rumah tangga dan perusahaan)
c) siswa membuat grafik/kurva tentang berlakunya hukum pertambahan hasil yang semakin berkurang. 
4) Mengkomunikasikan atau menyajikan hasil karya pada pembaca, teman sekelas, guru atau audiens lainnya.

a) menempelkan gambar/kurva di dinding, mempresentasikan di depan kelas untuk mendapatkan tanggapan/kelengkapan hasil pengamatan.

b) melakukan refleksi, memunculkan ide-ide baru, tanya-jawab dengan teman.

\section{c. Bertanya (Questioning)}

Pengetahuan yang dimiliki seseorang, selalu bermula dari bertanya. Sebelum tahu kota Palu, seseorang bertanya "Mana arah ke kota Palu?" Questioning merupakan strategi utama pembelajaran CTL. Bertanya dalam pembelajaran dipandang sebagai kegiatan guru untuk mendorong, membimbing, dan menilai kemampuan berpikir siswa. Bagi siswa kegiatan bertanya merupakan bagian penting dalam melaksanakan pembelajaran yang berbasis inkuiri, yaitu menggali informasi, mengkonfirmasikan apa yang sudah diketahui, dan mengarahkan perhatian pada aspek yang belum diketahui.

Dalam pembelajaran yang produktif, kegiatan bertanya berguna untuk :

1) menggali informasi, baik administrasi maupun akademis

2) mengecek pemahaman siswa

3) membangkitkan respons kepada siswa

4) mengetahui sejauh mana keingintahuan siswa
5) mengetahui hal-hal yang sudah diketahui siswa

6) memfokuskan perhatian siswa pada sesuatu yang dikehendaki guru

7) untuk membangkitkan lebih banyak lagi pertanyaan dari siswa

8) menyegarkan kembali pengetahuan siswa

Questioning dapat diterapkan di dalam kelas untuk hampir semua aktivitas belajar. Questioning dapat diterapkan : antara siswa dengan siswa, antara guru dengan siswa, antara siswa dengan guru, antara siswa dengan orang lain yang didatangkan ke kelas. Aktivitas bertanya juga ditemukan sewaktu siswa berdiskusi, kerja kelompok, ketika menemui kesulitan, ketika mengamati, ketika observasi, dan sebagainya.

\section{d. Masyarakat Belajar (Learning Community)}

Konsep learning community menyarankan agar hasil pembelajaran diperoleh dari kerjasama dengan orang lain. Ketika seorang anak baru belajar meraut pensil dengan peraut elektronik, ia bertanya kepada temannya " Bagaimana caranya ?" Tolong dong bantu aku! Lalu temannya yang sudah bisa, menunjukkan cara mengoperasikan alat itu. Maka kedua anak itu sudah membentuk masyarakat belajar.

Hasil belajar diperoleh dari sharing antara teman, antar kelompok, dan antara yang tahu ke yang belum tahu. Di ruang ini, di kelas ini, di sekitar sini, juga orang-orang yang berada di luar sana, 
semua adalah anggota masyarakat belajar. Dalam kelas guru disarankan selalu melaksanakan pembelajaran dalam kelompok-kelompok belajar. Yang pandai mengajari yang lemah, yang tahu memberi tahu yang belum tahu, yang cepat menangkap mendorong temannya yang lamban, yang mempunyai gagasan segera menyampaikan usul, dan seterusnya. Seorang guru juga dapat berkolaborasi dengan mendatangkan seorang ahli ke kelas. Misalnya tukang sablon, tukang cat mobil, ahli foto, petani buah, peternak burung, peternak lembu, teknisi komputer, teknisi elektronik, tukang kunci, dan sebagainya, teknisi motor/mobil, teknisi telepon genggam, dan sebagainya.

Masyarakat belajar dapat terjadi apabila ada proses komunikasi dua arah. Guru yang mengajari siswanya, bukan contoh kegiatan masyarakat belajar, karena komunikasi yang terjadi hanya satu arah. Informasi yang terjadi hanya datang dari guru, tidak ada informasi yang perlu dipelajari guru yang datang dari siswa. Seseorang yang terlibat dalam kegiatan masyarakat belajar, memberikan informasi yang diperlukan oleh temannya dan sekaligus juga meminta informasi yang diperlukan dari teman belajarnya.

Kegiatan masyarakat belajar akan berjalan baik, jika tidak ada pihak yang dominan, tidak ada yang merasa segan bertanya, tidak ada pihak yang merasa paling tahu, semua pihak mau saling mendengarkan. Jika setiap orang mau belajar dari orang lain, maka setiap orang menjadi sumber belajar, artinya setiap orang akan sangat kaya dengan pengetahuan dan pengalaman. Model pembelajaran dengan teknik learning community sangat membantu proses pembelajaran di kelas. Praktiknya dalam pembelajaran terwujud dalam :

1) pembentukan kelompok kecil

2) pembentukan kelompok besar

3) mendatangkan ahli, tokoh, olahragawan, dokter, perawat, petani, polisi, tukang kayu, teknisi, dan sebagainya ke kelas

4) bekerja dengan kelas sederajat

5) bekerja kelompok dengan kelas di atasnya

6) bekerja dengan masyarakat.

\section{e. Permodelan (Modeling)}

Dalam sebuah pembelajaran ketrampilan atau pengetahuan tertentu, ada model yang dapat ditiru. Model ini berupa cara mengoperasikan sesuatu, misalnya mengoperasikan komputer untuk program tertentu, mengoperasikan mesin hitung. Menggunakan internet, mengoperasikan komputer untuk pojok bursa, menggunakan peralatan di laboratorium bahasa, dan sebagainya. Guru bukanlah satu-satunya model, karena model dapat dirancang dengan melibatkan siswa untuk mengoperasikan suatu peralatan, bahkan model dapat pula didatangkan dari luar, misalnya:
1) Guru Ekonomi mendatangkan seorang pengusaha yang sukses, 
untuk memberikan penjelasan tentang kesuksesan usahanya.

2) Guru Ekonomi mendatang praktisi perbankan/manajer koperasi untuk memberikan penjelasan dalam memanaj organisasi di kantornya.

\section{f. Refleksi (Reflection)}

Refleksi juga bagian penting dalam pembelajaran dengan pendekatan CTL. Refleksi adalah cara berpikir tentang apa yang baru dipelajari atau berpikir ke belakang tentang apa-apa yang sudah kita lakukan di masa lalu. Siswa mengendapkan apa yang baru dipelajarinya sebagai struktur pengetahuan baru, yang merupakan pengayaan atau revisi dari pengetahuan sebelumnya. Refleksi merupakan respons terhadap kejadian, aktivitas, atau pengetahuan yang baru diterima. Misalkan ketika pelajaran berakhir, siswa merenung "Kalau begitu, informasi yang saya berikan kepada siswa untuk mencetak mata uang rupiah dilakukan oleh Peruri selama ini salah, ya". Ternyata mata uang rupiah kita dicetakkan di Australia.

Pengetahuan yang bermakna diperoleh dari proses. Pengetahuan dimiliki siswa diperluas melalui konteks pembelajaran, yang kemudian diperluas sedikit-demi sedikit. Guru atau orang dewasa membantu siswa membuat hubungan-hubungan antara pengetahuan yang dimiliki sebelumnya dengan pengetahuan yang baru. Dengan demikian siswa merasa memperoleh sesuatu yang berguna bagi dirinya tentang apa yang baru dipelajarinya.

Pada akhir pembelajaran guru menyisakan waktu sejenak agar siswa melakukan refleksi. Realisasinya berupa: pertanyaan langsung tentang apa-apa yang diperolehnya pada hari itu, catatan atau jurnal di buku siswa, kesan dan saran siswa mengenai pembelajaran hari itu, diskusi, dan hasil karya.

\section{g. Penilaian Yang Sebenarnya (Authentic Assessment)}

Assessment adalah proses pengumpulan berbagai data yang bisa memberikan gambaran perkembangan belajar siswa. Gambaran perkembangan belajar siswa perlu diketahui oleh guru agar dapat memastikan bahwa siswa mengalami proses pembelajaran dengan benar. Apabila data yang dikumpulkan guru mengindentifikasikan bahwa siswa mengalami kemacetan dalam belajar, maka guru dapat segera mengambil tindakan yang tepat agar siswa terbebas dari kemacetan belajar. Berhubung gambaran kemajuan belajar siswa diperlukan sepanjang proses pembelajaran, maka assessment tidak dilakukan di akhir periode (cawu/semester) pembelajaran seperti kegiatan evaluasi hasil belajar (EBTA/EBTANAS), tetapi dilakukan bersama secara terintegrasi (tidak terpisahkan) dari kegiatan pembelajaran.

Data yang dikumpulkan dari kegiatan penilaian (assessment) bukanlah untuk mencari informasi tentang belajar siswa. 
Pembelajaran yang benar memang seharusnya ditekankan pada upaya membantu siswa agar mampu mempelajari (learning how to learn), bukan ditekankan pada diperolehnya sebanyak mungkin informasi di akhir periode pembelajaran. Karena assessment menekankan proses pembelajaran, maka data yang dikumpulkan harus diperoleh dari kegiatan nyata yang dikerjakan siswa pada saat melakukan proses pembelajaran. Data yang diperoleh dari kegiatan pembelajaran di dalam kelas maupun di luar kelas inilah yang disebut data otentik.

Kemajuan belajar dinilai dari proses, bukan melulu hasil, dan dengan berbagai cara. Tes hanyalah salah satunya, dan inilah hakikat penilaian yang sebenarnya. Penilaian otentik menilai pengetahuan dan ketrampilan (performasi) yang diperoleh siswa. Penilai tidak hanya guru, tetapi teman lain bahkan orang lain.

Karakteristik authentic assessment,

1) dilaksanakan selama dan sesudah proses pembelajaran berlangsung

2) bisa digunakan untuk formatif maupun sumatif

3) yang diukur ketrampilan dan performasi, bukan mengingat fakta/dalil

4) berkesinambungan

5) terintegrasi

6) dapat dipergunakan sebagai umpan balik (feedback)
Hal-hal yang dapat dipergunakan sebagai dasar menilai prestasi siswa yaitu : proyek/kegiatan dan laporan, PR, kuis, karya siswa, presentasi atau performasi siswa

demonstrasi, laporan, jurnal, hasil tes, karya tulis.

\section{Karakteristik Pembelajaran} Berbasis CTL

Beberapa karakteristik Pembelajaran Berbasis Contextual Teaching and Learning;

a. Kerjasama

b. Saling menunjang

c. Menyenangkan, tidak membosankan

d. Belajar dengan gairah

e. Pembelajaran terintegrasi

f. Menggunakan berbagai sumber

g. Siswa aktif

h. Sharing dengan teman

i. Siswa Kritis, dan Guru Kreatif

j. Dinding kelas \& lorong-lorong penuh dengan hasil karya siswa, peta-peta, gambar, artikel, humor, dan lain sebagainya

k. Laporan kepada orang tua bukan hanya rapor, tetapi hasil karya siswa, laporan hasil praktikum, karangan siswa, dan sebagainya.

\section{Menyusun Rencana} Pembelajaran Berbasis Kontekstual

Dalam pembelajaran kontekstual, program pembelajaran lebih merupakan rencana kegiatan kelas yang dirancang guru, yang berisi skenario tahap-demi tahap tentang apa yang akan dilakukan 
bersama siswanya sehubungan dengan topik yang akan dipelajari. Dalam program tercermin tujuan pembelajaran, media untuk mencapai tujuan, langkahlangkah pembelajaran, dan authentic assessment-nya.

Tentunya berbeda dengan program yang dikembangkan oleh paham objektivis, penekanan program yang berbasis kontekstual bukan pada rincian, dan kejelasan tujuan, tetapi pada gambaran kegiatan tahap-demi tahap dan media yang dipakai. Rumusan tujuan yang kecil-kecil, bukan menjadi prioritas dalam penyusunan rencana pembelajaran berbasis $\mathrm{CTL}$, mengingat yang akan dicapai "bukan hasil" tetapi lebih pada "strategi belajar". Yang diinginkan "bukan banyak tetapi dangkal", melainkan "sedikit tetapi mendalam". Dalam konteks ini, program yang dirancang guru benar-benar rencana pribadi tentang apa yang akan dikerjakan bersama siswanya. Gambaran selama ini bahwa RP (Rencana Pembelajaran) adalah laporan untuk kepala sekolah atau pihak lain harus dibuang jauh-jauh. RP-lah yang mengingatkan guru tentang benda apa yang harus dipersiapkan, alat apa yang harus dibawa, berapa banyak, ukurannya berapa, dan langkah-langkah apa yang akan dikerjakan siswa. RP-lah yang mengingatkan guru ketika akan berangkat ke sekolah untuk menyiapkan segala sesuatunya, untuk kegiatan pembelajaran di sekolah.
Secara umum tidak ada perbedaan yang mendasar format antara program pembelajaran konvensional dengan program pembelajaran kontekstual. Yang berbeda hanyalah pada penekanannya, program pembelajaran konvensional lebih menekankan pada deskripsi tujuan yang akan dicapai (jelas dan operasional), sedangkan program pembelajaran kontekstual lebih menekankan pada skenario pembelajarannya.

Atas dasar itulah, saran pokok dalam penyusunan program pembelajaran (RP) berbasis kontekstual adalah sebagai berikut.

a. Nyatakan kegiatan utama pembelajarannya, yaitu sebuah pernyataan kegiatan siswa yang merupakan gabungan antara Kompetensi Dasar, Materi Pokok, dan Indikator Pencapaian Hasil Belajar (IPHB).

b. Nyatakan tujuan umum pembelajarannya (lihat pada IPHB)

c. Rincilah media untuk mendukung kegiatan itu

d. Buatlah skenario tahap-demi tahap kegiatan siswa

e. Nyatakan authentic assessment-nya, yaitu dengan data apa siswa dapat diamati partisipasinya dalam pembelajaran.

\section{F. Kesimpulan}

Secara diametral model pembelajaran dapat dibedakan menjadi dua model, 
yaitu model ekspositori (expository penerapannya dalam kehidupan mereka method) dan model inkuiri (inquiry sebagai anggota keluarga dan teaching method). Berbagai model masyarakat. Sehingga pembelajaran ini pembelajaran yang jumlahnya cukup bermakna bagi siswa.

banyak terletak di antara dua model Penerapan Pendekatan kontekstual di tersebut. Inkuiri merupakan model dalam kelas melibatkan tujuh komponen pembelajaran yang berpusat pada siswa. utama pembelajaran efektif, yakni Yaitu model pembelajaran yang konstruktivisme, bertanya, inkuiri, menempatkan siswa dalam situasi di masyarakat belajar, permodelan, refleksi, mana mereka harus berpartisipasi aktif untuk menemukan sesuatu untuk mereka sendiri

Pembelajaran kontekstual (Contextual Teaching and Learning) yang biasa disingkat CTL, merupakan salah satu model yang dekat ke arah model inkuiri. Dalam tulisan ini model pembelajaran CTL menjadi pilihan untuk melaksanakan pembelajaran ekonomi dalam kurikulum berbasis kompetensi.

Pendekatan kontekstual merupakan konsep belajar yang membantu guru mengaitkan antara materi dengan situasi dunia nyata siswa, dan mendorong siswa membuat hubungan antara pengetahuan yang dimiliki dengan dalam dan penilaian otentik. Suatu kelas dikatakan menggunakan pembelajaran kontekstual, jika melaksanakan ke tujuh komponen tersebut.

Dalam penyusunan Rencana Pembelajaran (RP) ditekankan pada strategi belajar. Bukan yang banyak tapi dangkal, melainkan sedikit tapi mendalam. Konteks ini, program yang dirancang guru benar-benar rencana pribadi tentang apa yang akan dikerjakan bersama siswanya.

Semoga sentuhan tulisan ini ada manfaatnya bagi para pembaca, terutama yang mencintai dan menggeluti dunia pendidikan.

\section{Daftar Pustaka}

Anonim. (2003). Contextual Teaching and Learning (CTL), Direktorat PLP, Dirjen Dikdasmen Departemen Pendidikan Nasional, Jakarta.

Ausubel, David. (1979). Educational Psychology (a cognitive view)

Block, James H. (1971). Mastery Learning: Theory and Practice. Holt. Rinehart and Winston.Inc., New York.

Dasim Budimansyah. (2002). Model Pembelajaran dan Penilaian Portofolio. PT Genesindo, Bandung 
Dewey, J. (1974). Experience \& Education. The University of Chicago Press, New Yorka.

Mc Ashan, H.H. (1979). Competency Based Education and Behavioral Objective. J ersy; Educational Technology Publication, Inc. USA

Oemar hamalik. (1993). Strategi Belajar Mengajar. Mandar Maju, Bandung.

Slamet PH. (2003). Pendidikan Kecakapan Hidup (Life Skills). Makalah disampaikan dalam TOT guru-guru SMP dan MTs. Enam Propinsi Indonesia Wilayah Tengah di BPG Kalasan Yogyakarta. Direktorat PLP-Dirjen Dikdasmen-Depdiknas, Jakarta.

Slavin, Robert E. (1981). Synthesis of Research on Cooperative Learning, Educational Leadership, Mc Graw Hill Book Company, New York.

Sunarto. (1989). Strategi Belajar Mengajar I/mu Pengetahuan Sosial, IKIP Malang, Malang.

Tim. (2003). Pembelajaran Tuntas (Mastery Learning). Direktorat PLP Dirjen Dikdasmen. Departemen Pendidikan Nasional, J akarta.

Winarno Surakhmad. (1994). Pengantar Interaksi Mengajar Belajar, Dasar dan Teknik Metodologi Pengajaran. Tarsito, Bandung

Zahorik, J ohn A. (1995). Contructivist Teaching (Fastback 390). Bloomington, Indiana. Phii-Delta Kappa Education Foundation.

Zamroni. (1991). Model-Model Pengajaran (Aplikasi Teori Pembelajaran Dalam Proses Belajar Mengajar Suatu Pendekatan Praktis). FPIPS IKIP Muhammadiyah Purworejo, Purworejo. 